\title{
EXCLUSIVE BREASTFEEDING AND MATERNAL SELF-EFFICACY AMONG WOMEN OF INTIMATE PARTNER VIOLENCE SITUATIONS
}

\author{
Laura Marina Bandim Marianoㄴ, Juliana Cristina dos Santos Monteiro², Juliana Stefanello³, Flávia Azevedo \\ Gomes-Sponholz ${ }^{4}$, Mônica Oliveira Batista Oriáa ${ }^{5}$ Ana Márcia Spanó Nakano ${ }^{6}$
}

\begin{abstract}
${ }^{1}$ M.Sc. in Maternal - Infant Health. Nurse. Hospital das Clínicas de Ribeirão Preto Ribeirão Preto. São Paulo, Brazil E-mail: laurabandim@ usp.br

2 Ph.D. in Nursing in Public Health. Professor, Departamento de Enfermagem Materno-Infantil e Saúde Pública (DEMISP) in the Escola de Enfermagem de Ribeirão Preto (EERP) in the Universidade de São Paulo (USP). Ribeirão Preto, São Paulo, Brazil. E-mail: jumonte@ eerp.usp.br

${ }^{3}$ Ph.D. in Nursing in Public Health. Professor in DEMISP, EERP/USP. Ribeirão Preto, São Paulo, Brazil. E-mail: julianas@eerp.usp.br

${ }^{4}$ Tenured Professor. Professor in DEMISP, EERP/USP. Ribeirão Preto, São Paulo, Brazil. E-mail: flagomes@eerp.usp.br

${ }^{5}$ Ph.D. in Nursing. Professor, Universidade Federal do Ceará. Fortaleza, Ceará, Brazil. E-mail: profmonicaoria@gmail.com

${ }^{6}$ Tenured Professor. Professor, DEMISP, EERP/USP. Ribeirão Preto, São Paulo, Brazil. E-mail: nakano@eerp.usp.br
\end{abstract}

\begin{abstract}
This study aims to evaluate the practice of breastfeeding among women in intimate partner violence situation during the current pregnancy for the duration of exclusive breastfeeding, the level of self-efficacy in breastfeeding, related factors from the beginning, the establishment of breastfeeding and early weaning. Cross-sectional study. 63 women in intimate partner violence situation in the current pregnancy participated, identified by survey in antenatal service. Data collection was performed in the prenatal and postpartum period. We used a questionnaire to identify the intimate partner violence, the Breastfeeding Self-Efficacy Scale and medical record information. The average days of exclusive breastfeeding was 19.08. There was no statistically significant association between the duration of exclusive breastfeeding at 30 and 70 days postpartum and intimate partner violence and care practices with level of self-efficacy to breastfeed. We found association between the type of breastfeeding at 30 and 70 days postpartum and better conditions vital of newborns with level of self-efficacy to breastfeed. DESCRIPTORS: Violence. Genre. Breastfeeding. Self-efficacy.
\end{abstract}

\section{ALEITAMENTO MATERNO EXCLUSIVO E AUTOEFICÁCIA MATERNA ENTRE MULHERES EM SITUAÇÃO DE VIOLÊNCIA POR PARCEIRO ÍNTIMO}

RESUMO: Este estudo busca analisar a prática da amamentação entre mulheres em situação de violência por parceiro íntimo durante a gestação atual quanto à duração do aleitamento materno exclusivo, o nível de autoeficácia para amamentar e fatores relacionados ao início, estabelecimento da amamentação e desmame precoce. Trata-se de um estudo transversal. Participaram 63 mulheres em situação de violência por parceiro íntimo na gestação atual, identificadas por inquérito em serviço pré-natal. A coleta de dados foi realizada no prénatal e pós-parto. Utilizou-se questionário de identificação da violência por parceiro íntimo, a Breastfeeding Self-Efficacy Scale e informações dos prontuários. A média em dias de aleitamento materno exclusivo foi de 19,08. Não houve associação estatisticamente significativa entre a duração do aleitamento materno exclusivo com 30 e 70 dias pós-parto e tipos de violência por parceiro íntimo, bem como práticas assistenciais com nível de autoeficácia para amamentar. Verificamos associação entre o tipo de aleitamento materno com 30 e 70 dias pósparto e melhores condições vitais do recém-nascido com nível de autoeficácia para amamentar.

DESCRITORES: Violência. Gênero. Amamentação. Autoeficácia.

\section{LACTANCIA MATERNA EXCLUSIVA Y AUTOEFICACIA MATERNA ENTRE MUJERES EM SITUACIONES DE VIOLENCIA EM LA PAREJA}

RESUMEN: Este estúdio tiene como evaluar la práctica de la lactancia materna entre mujeres em situación de violência del compañero íntimo durante elembarazo actual para la duración de lan lactancia materna exclusiva, el nivel de autoeficacia de amamantar y factores relacionados a la iniciación, el establecimiento de la lactancia y el destete precoz. Estudio transversal. 63 mujeres participaron em situación de violência del compañero íntimo em el embarazo actual, identificado por encuesta em el servicio prenatal. La recolección de datos se realizo em el prenatal y postparto. Se utilizo um cuestionario de identificación de violência del compañero íntimo, Breastfeeding Self-Efficacy Scale y información de los registros médicos. El promedio de días de lactancia materna exclusiva fue 19,08. No hubo asociacióne stadísticamente significativa entre la duración de la lactancia materna exclusiva a los 30 y 70 días después del parto y tipos de violência del compañero, asi como prácticas de cuidado con nível de autoeficacia de amamentar. Se encontro asociación entre el tipo de lactancia materna a los 30 y 70 días después del parto y mejores condiciones vitales de lo recien nacido con el nível de autoeficacia de amamentar.

DESCRIPTORES: Violencia. Género. Amamantamiento. Autoeficacia. 


\section{INTRODUCTION}

Breastfeeding is not only a biological action, but a combination of historical, educational, social, anatomical, cultural and psychological factors. ${ }^{1}$ For those who live in situations of violence, this reality may be an important risk factor for premature weaning as shown in the consulted studies. ${ }^{2-3}$ In the amplitude in this research field, the literature shows incipient and controversial studies on violence during pregnancy and in the postpartum period, and particularly about its effects on breastfeeding, most are conducted in developed countries and seek to evaluate only the duration of exclusive breastfeeding. In Brazil, among mothers of children under five months of age in different regions of the city of Rio de Janeiro, it is noted that $18.9 \%$ of respondents reported severe physical violence during pregnancy and found a statistically significant association between severe physical violence during pregnancy and the interruption of exclusive breastfeeding with ratios rates of 1.35 (95\% CI: 1.04, 1.75) and 1.31 (95\% CI: $1.01 ; 1.69)$ respectively. ${ }^{3}$

Violence committed against women, the object of this study, is based on the definition of the Inter-American Convention on the Prevention, Punishment and Eradication of Violence against Women, being defined as "any act or conduct, based on gender, which causes death, damage or physical suffering, sexual or psychological to women, whether in the public or the private sphere" ${ }^{4: 19}$ When this violence occurs in an intimate relationship, it is defined as intimate partner violence. ${ }^{5}$

The partner's aggressive attitude, regardless of place, before, during and/or after pregnancy, can constitute a risk factor for the mother not breastfeeding. This situation seems to bring these women a physical and emotional exhaustion that ends up reflecting in the care of the children. ${ }^{2}$ The woman who lives in psychological distress may have changes in her self-efficacy in relation to breastfeeding. ${ }^{6}$ Regarding confidence in The Cognitive Social Theory or Self-efficacy theory, ${ }^{7}$ the individual's level of confidence in their abilities is a strong motivator and regulates their behavior. The individual who realizes their ability to perform a certain task puts more effort into doing it, has more motivation to complete it and perseveres for longer on the realization then those with low self-efficacy. Applying this concept to breastfeeding, Dennis and Faux developed self-efficacy studies in nursing, understanding that confidence or self-efficacy in breastfeeding is the fact that women have sufficient knowledge and skills to successfully breastfeed their baby. 8 .
This study is justified by the importance of knowing and analyzing aspects poorly understood in the scientific literature about the influence of intimate partner violence during pregnancy and in the breastfeeding process, including the study question: can intimate partner violenceduring pregnancy interfere with women's self-efficacy to breastfeed and become a risk factor for premature weaning? The answer to this question could bring information to health professionals and give greater visibility to the problem in question and allow them to work to minimize the consequences.

In the scope of this research field we had to analyze the practice of breastfeeding among women attending a public prenatal service in intimate partner violence situations during the current pregnancy, and the duration of exclusive breastfeeding, the level of maternal self-efficacy to breastfeed and factors related to the beginning of breastfeeding and premature weaning.

\section{METHOD}

This is a transversal study, developed in the Centro de Referência da Saúde da Mulher (Women's Health Reference Center) (CRSM) - MATER, located in Ribeirão Preto, São Paulo, Brazil. This study is part of a survey on the prevalence of intimate partner violence in the current pregnancy in a population composed of pregnant women who received prenatal care at CRSM MATER. The sample size calculation was based on the number of visits in one year, using Power Analysis and Sample Size program (PASS) version 2002, based on a finite population of 1,600 pregnant women, with $4 \%$ accuracy for an estimate with $95 \%$ confidence, totaling 358 participants. From this calculation, the sample was selected in a systematical and probabilistic way, with a sampling interval of four, having the first sample unit obtained by raffle in the software Statistical Package for Social Sciences (SPSS), initiated in May 2012 and completed in May 2013.

In this survey, we sought to characterize the practice of breastfeeding among victims of intimate partner violence during their current pregnancy, totaling 63 women. Data collection was performed prenatally through application forms on socio-demographic, economic, behavioral, obstetric data and the identification instrument of the period of occurrence and characterization of violence (physical, sexual and/or psychological). The instrument belongs to the public domain, provided by the World Organization health ${ }^{9}$ and validated by Schraiber and collaboraters. ${ }^{10}$ For the field work, 
six interviewers were selected, including the responsible researcher, who participated in training in order to operationalize the data collection and avoid biases. The questions were answered at this point. The interviews were conducted in the same service in a private place without the presence of a companion, after receiving information about the purpose of the research, they agreed to participate and signed the consent forms.

Of the 63 women sampled for this study section, 50 attended because 13 were excluded during the phases described below.

Data were collected from the participants and their newborn children during the maternity hospital stay. At this time, an instrument built specifically for this study was used which included obstetric and neonatal variables. This information was obtained from medical records, which contained printed forms for registration of maternal and neonatal data filled by the medical and nursing staff. Another phase of the collection was carried out within 30 days postpartum, visiting the home of participants, held only by the responsible researcher, when it was applied to The Breastfeeding Self-Efficacy Scale (BSES) to evaluate self-efficacy in the breastfeeding process.

The breastfeeding Self-efficacy Scale, validated for the Portuguese language in Brazil is a Likert scale, containing 33 questions divided into two areas: technical and intrapersonal thought. Each question has five possible answers, with scores ranging from 1 to 5, with 1 - strongly disagree; 2 - disagree; 3 sometimes agree; 4 - I agree; 5 - totally agree. Thus, the total scores of the scale ranges between 33-165 points. ${ }^{11-12}$ Confidence in breastfeeding identified by the scale is distributed according to the scores obtained from the sum of each issue: confidence or low effectiveness (33 to 118 points), confidence or average effectiveness (119-137 points), confidence or high effectiveness (138-165 points). In addition to the data collection, data was obtained relating to the complications which occurred or not, the type of breastfeeding practiced and the factors that influenced weaning.

In the period of 70 days postpartum, we sought information through telephone contact, about the type of breastfeeding and the factors that influenced weaning. The characterization of the type of breastfeeding was analyzed based on the indicators defined by WHO in 1991 and updated in 2008.

The indicators that we consider in this study were: exclusive breastfeeding -a child receives only breast milk directly from the breast or extracted and no other liquids or solids except medicine or vitamin supplements; Predominant Breastfeeding -a child receives breast milk directly from the breast or extracted, and water or water-based beverages (teas, juices) and no other liquid or solid food; Breastfeeding- a child receives breast milk directly from the breast or extracted, independent from receiving any liquid or solid food, including other milks; Weaning - when the child no longer receives breast milk, but other types of milk or other liquids or solid foods. ${ }^{13}$

In the data analysis, we used descriptive statistics to characterize the sample. To determine the association between the qualitative variables, the data were submitted to Fisher's Exact Test. We used the Student t-tests, which consist of comparing two means from unpaired samples. In this sense, it was necessary to test whether the variances of the two groups were statistically equal, and if the data followed a normal distribution. To carry out this procedure, we used the PROC TTEST procedure of SAS® Software 9.0. For comparisons, we used Analysis of Variance - ANOVA. For all variables correlation tests, a significance level of $5 \%$ was considered, ie, differences were identified as statistically significant when p-value was less than 0.05.

As for the ethical aspects, the standards were followed for research involving human beings established by the National Council Resolution of Health N. 466/2012. ${ }^{14}$ The project was approved by the Research Ethics Committee (protocol 1421/2011) in Escola de Enfermagem de Ribeiraão Preto da Universidade de São Paulo.

\section{RESULTS}

\section{Sociodemographic profile}

In this population, the prevalence of intimate partner violence during pregnancy was $17.59 \%$. Of the 63 women who reported suffering violence during pregnancy, 50 participated in all data collection steps. The average age of participants was 24.50 years. Regarding education, the average years studied was 8.94. As for self-referred color, there was a higher percentage of women who considered themselves as mixed race ( $40 \%)$, followed by who considered themselves as white $(30 \%)$. As regards to occupation, $30 \%$ reported performing domestic housework and in the formal market and followed by that were $24 \%$ who were unemployed. The highest percentage of women were evangelical (38\%), followed by Catholic with $36 \%$. Most respondents $(56 \%)$ said that the householder was their companion. Only $26 \%$ of participants were married, but the majority $(74 \%)$ lived in marital status. The 
average duration of the relationship in months was 62.14. Most of them reported not smoking and using alcohol, $86 \%$ and $84 \%$, respectively. In relation to the use of illicit drugs, all participants denied use.

Regarding obstetric variables, most of the women interviewed (66\%) were in their first or second pregnancy, and, most, primipara. As for the planning and the desire of pregnancy, $70 \%$ of respondents revealed not having planned the current pregnancy, and $26 \%$ were not wanted.

Most (94\%) of the 50 participants in this study suffered psychological violence by their partner during the current pregnancy, $42 \%$ of them suffered physical violence and $2 \%$ sexual. Although all participants have referred to some violent act by their partners during the pregnancy, only $36 \%$ had the perception of being victims of violence. Another aspect investigated is the perception of the same in relation to violence affecting their health or not, and $30 \%$ of women said yes.

\section{Clinical profile}

We can observe that $48 \%$ of participants began their prenatal visits in the first trimester and most performed over six visits during the prenatal period. $46 \%$ of participants had some complications during pregnancy and $30 \%$ had complications in childbirth. It is worth considering that the maternity clinic, the setting of this study, attends low and medium risk pregnant women, the pregnancies with the most serious complications are redirected to high-risk services.

Regarding the type of delivery, half of the study participants had vaginal delivery. In $46 \%$ of deliveries analgesia was performed. 45 mothers had companions during their delivery, and the majority of these being their partner $(60 \%)$, and two participants had no such information in the medical record. Most babies (90\%) were born full term. The mean gestational age in days was 276.81 . Most babies (72\%) were born weighing between 3000-3999 grams, 86\% of newborns had the Apgar score of 7 to 10 in the first minute of life, and 98\% had the same Apgar score in the fifth minute of life. In the neonatal period, $30 \%$ had some complications at birth and $22 \%$ had some complications during hospitalization.

\section{Breast-feeding}

Regarding breastfeeding practice characteristics, based on information obtained from medical records, most babies (62\%) did not suckle in the first hour of life, and $40 \%$ had immediate contact with their mothers in the delivery room. However, ten children did not have this information recorded in the medical record. With regard to the type of feeding at discharge, most babies (88\%) left the maternity exclusively breastfeeding. It was observed that, with 30 days postpartum, $94 \%$ of babies were being breastfed, but only $55.32 \%$ were being breastfed exclusively. The average time exclusively breastfeeding in days was 19.08, with a maximum time of 32 days. With regard to complications with breast-feeding during this period, half of the women experienced some type of problem and the most frequent being nipple trauma $(92 \%)$. After 70 days postpartum, it was found that $40 \%$ of mothers were breastfeeding exclusively, $18 \%$ had offered water or tea to their children, $12 \%$ were already offering other milk, in addition to breastmilk, and $16 \%$ had already weaned their babies, and seven women did not answer this questionnaire.

\section{Self-efficacy in nursing}

In relation to maternal self-efficacy to breastfeed, assessed at 30 days postpartum, $12 \%$ of study participants had low self-efficacy, 34\% had average self-efficacy and $54 \%$ had high self-efficacy. In association analysis, there was no statistically significant association between the duration of exclusive breast feeding 30 days postpartum and the occurrence of types of intimate partner violence in the current pregnancy. There was no association with the type of breastfeeding at 70 days postpartum and the occurrence of violence during pregnancy. Regarding the level of self-efficacy in breastfeeding and the type of violence that occurred during the pregnancy, we found that regardless of the type of violence, there was no change in the distribution profile of the self-efficacy level between the participants, i.e. the highest percentage of responses is presented as high self-efficacy, followed by medium and low self-efficacy.

Table 1 shows the association between the type of breastfeeding carried out 30 and 70 days after delivery and self-efficacy level for breastfeeding, which was statistically significant, according to Fisher's exact test p-value of 0.0226 and 0.0300 , respectively. Most women with high self-efficacy $(52 \%)$ were breastfeeding 30 days postpartum, and $38.3 \%$ of them practiced exclusive breastfeeding. 70 days postpartum, the 43 women who completed the questionnaire, $34.88 \%$ who had high self-efficacy practiced exclusive breastfeeding. 
Table 1 - Distribution of participants, according to the self-efficacy level of breastfeeding associated with the type of breastfeeding. Ribeirão Preto-SP, Brazil, 2013. $(n=50)$

\begin{tabular}{|c|c|c|c|c|c|c|c|}
\hline \multirow{3}{*}{ Variables } & \multicolumn{6}{|c|}{ Self-Efficacy in Breastfeeding } & \multirow{3}{*}{ p-value } \\
\hline & \multicolumn{2}{|c|}{ Low } & \multicolumn{2}{|c|}{ Medium } & \multicolumn{2}{|c|}{ High } & \\
\hline & $\mathbf{n}$ & $\%$ & $\mathbf{n}$ & $\%$ & $\mathbf{n}$ & $\%$ & \\
\hline \multicolumn{8}{|l|}{ Breastfeeding at 30 days $(n=50)$} \\
\hline Yes & 4 & 8,00 & 17 & 34,00 & 26 & 52,00 & \multirow{2}{*}{$0,0347^{*}$} \\
\hline No & 2 & 4,00 & - & - & 1 & 2,00 & \\
\hline \multicolumn{8}{|c|}{ If yes, is it exclusive breastfeeding $(n=47)$} \\
\hline Yes & - & 0,00 & 8 & 17,02 & 18 & 38,30 & \multirow{2}{*}{$0,0226^{*}$} \\
\hline No & 4 & 8,51 & 9 & 19,15 & 8 & 17,02 & \\
\hline \multicolumn{8}{|c|}{ Type of breastfeeding at 70 days $(n=43)$} \\
\hline Exclusive Breastfeeding & - & - & 5 & 11,63 & 15 & 34,88 & \multirow{4}{*}{$0,0300^{\prime}$} \\
\hline Predominantly Breastfeeding & - & - & 5 & 11,63 & 4 & 9,30 & \\
\hline Breastfeeding & 1 & 2,33 & 2 & 4,65 & 3 & 6,98 & \\
\hline Weaned & 3 & 6,98 & 3 & 6,98 & 2 & 4,65 & \\
\hline
\end{tabular}

Fisher's Exact Test; * Statistically significant value.

Among the factors considered in this study the includes obstetrical variables (Table 2), neonatal possible ways to influence breastfeeding practice (Table 3) and assistance (Table 4).

Table 2 - Distribution of participants according to the self-efficacy level of breastfeeding associated with obstetric variables. Ribeirão Preto-SP, Brazil, 2013. (n=50)

\begin{tabular}{|c|c|c|c|c|c|c|c|}
\hline \multirow{3}{*}{ Variables } & \multicolumn{6}{|c|}{ Self-Efficacy in breastfeeding } & \multirow{3}{*}{ p-value } \\
\hline & \multicolumn{2}{|c|}{ Low } & \multicolumn{2}{|c|}{ Medium } & \multicolumn{2}{|c|}{ High } & \\
\hline & $\mathbf{n}$ & $\%$ & $\mathbf{n}$ & $\%$ & $\mathbf{n}$ & $\%$ & \\
\hline \multicolumn{8}{|c|}{ Gestational age at beginning of pre-natal care } \\
\hline 1st trimester & 2 & 5,26 & 7 & 18,42 & 15 & 39,47 & \multirow{3}{*}{0,6952} \\
\hline 2nd trimester & 2 & 5,26 & 5 & 13,16 & 7 & 18,42 & \\
\hline 3rd trimester & - & - & - & - & - & - & \\
\hline \multicolumn{8}{|c|}{ Number of pre-natal consultations } \\
\hline$<6$ & - & - & 1 & 2,13 & - & - & \multirow[b]{2}{*}{0,4468} \\
\hline$\geq 6$ & 4 & 8,51 & 16 & 34,04 & 26 & 55,32 & \\
\hline \multicolumn{8}{|l|}{ Type of delivery } \\
\hline Vaginal & 3 & 6,00 & 9 & 18,00 & 13 & 26,00 & \multirow{3}{*}{1,0000} \\
\hline Cesarean & 3 & 6,00 & 8 & 16,00 & 13 & 26,00 & \\
\hline Forceps & - & - & - & - & 1 & 2,00 & \\
\hline \multicolumn{8}{|c|}{ Complications in pregnancy } \\
\hline Yes & 2 & 4,00 & 8 & 16,00 & 13 & 26,00 & \multirow{2}{*}{0,8496} \\
\hline No & 4 & 8,00 & 9 & 18,00 & 14 & 28,00 & \\
\hline \multicolumn{8}{|c|}{ Complications in delivery } \\
\hline Yes & 3 & 6,00 & 3 & 6,00 & 9 & 18,00 & \multirow{2}{*}{0,3058} \\
\hline No & 3 & 6,00 & 14 & 28,00 & 18 & 36,00 & \\
\hline \multicolumn{8}{|c|}{ Complications post delivery } \\
\hline Yes & - & - & 8 & 16,00 & 12 & 24,00 & \multirow{2}{*}{0,1188} \\
\hline No & 6 & 12,00 & 9 & 18,00 & 15 & 30,00 & \\
\hline
\end{tabular}

Fischer's Exact Test 
Obstetric variables were not associated with the level of maternal self-efficacy to breastfeed, while $39.47 \%$ of women who began their prenatal care in the first quarter, had a high level of self-efficacy in breastfeeding, while only $18.42 \%$ of those started in the second quarter, had the same level. This also occurred in the number of prenatal consultations, i.e., although there was no association, most women $(55.32 \%)$ who made six visits or more had high self -efficacy in breastfeeding.

In relation to neonatal variables we can see statistically significant results according to Fisher's exact test $p$-value of 0.0001, compared to the Apgar in first minute of life and self-efficacy in breastfeeding. $50 \%$ of mothers whose children had Apgar in the first minute, with a value of 7 to 10, had high self-efficacy in breastfeeding.

Table 3 - Distribution of participants, according to the self-efficacy level of breastfeeding associated with neonatal variables. Ribeirão Preto-SP, Brazil, 2013. $(n=50)$

\begin{tabular}{|c|c|c|c|c|c|c|c|}
\hline \multirow{3}{*}{ Variables } & \multicolumn{6}{|c|}{ Self-Efficacy in Breastfeeding } & \multirow{3}{*}{ p-value } \\
\hline & \multicolumn{2}{|c|}{ Low } & \multicolumn{2}{|c|}{ Medium } & \multicolumn{2}{|c|}{ High } & \\
\hline & $\mathbf{n}$ & $\%$ & $\mathbf{n}$ & $\%$ & $\mathbf{n}$ & $\%$ & \\
\hline \multicolumn{8}{|c|}{ Gestational age of birth in days } \\
\hline$<259$ & 1 & 2,00 & - & - & 2 & 4,00 & \multirow{3}{*}{0,1514} \\
\hline 259 to 293 & 5 & 10,00 & 15 & 30,00 & 25 & 50,00 & \\
\hline 294 or + & - & - & 2 & 4,00 & - & - & \\
\hline \multicolumn{8}{|c|}{ Apgar 1st minute } \\
\hline$\leq 3$ & 2 & 4,00 & - & - & 1 & 2,00 & \multirow{3}{*}{$<0,0001^{*}$} \\
\hline 4 to 6 & 3 & 6,00 & - & - & 1 & 2,00 & \\
\hline 7 to 10 & 1 & 2,00 & 17 & 34,00 & 25 & 50,00 & \\
\hline \multicolumn{8}{|c|}{ Apgar 5th minute } \\
\hline$<7$ & 1 & 2,00 & - & - & - & - & \multirow{2}{*}{0,1200} \\
\hline 7 to10 & 5 & 10,00 & 17 & 34,00 & 27 & 54,00 & \\
\hline \multicolumn{8}{|c|}{ Birth weight in grams } \\
\hline$<2.500$ & 2 & 4,00 & 2 & 4,00 & - & - & \multirow{4}{*}{0,1546} \\
\hline 2.500 to 2.999 & - & 0,00 & 3 & 6,00 & 5 & 10,00 & \\
\hline 3.000 to 3.999 & 4 & 8,00 & 11 & 22,00 & 21 & 42,00 & \\
\hline$\geq 4.000$ & - & - & 1 & 2,00 & 1 & 2,00 & \\
\hline
\end{tabular}

Fisher's Exact Test; * Statistically significant value

Regarding care practices, the fact that infants had not suckled or had not suckled in the first hour of life and had had immediate skin to skin contact with the mother, had no statistically significant association, as shown in Table 4 . However, the fact that the baby did not present complications during hospitalization or had remained rooming with the mother was associated with self-efficacy in breastfeeding, Fisher's exact test p-value of 0.0214 and 0.0058 , respectively.

Table 4 - Distribution of participants, according to the self-efficacy level of breastfeeding associated with care practices and complications during hospitalization. Ribeirão Preto, 2013. (n=50)

\begin{tabular}{|c|c|c|c|c|c|c|c|}
\hline \multirow{3}{*}{ Variables } & \multicolumn{6}{|c|}{ Self-Efficacy in Breastfeeding } & \multirow{3}{*}{ p-valor } \\
\hline & \multicolumn{2}{|c|}{ Low } & \multicolumn{2}{|c|}{ Medium } & \multicolumn{2}{|c|}{ High } & \\
\hline & $\mathbf{n}$ & $\%$ & $\mathbf{n}$ & $\%$ & $\mathbf{n}$ & $\%$ & \\
\hline \multicolumn{8}{|c|}{ Suckled in the 1st hour of life } \\
\hline Yes & - & - & 3 & 7,50 & 6 & 15,00 & 0,7527 \\
\hline No & 4 & 10,00 & 11 & 27,50 & 16 & 40,00 & \\
\hline \multicolumn{8}{|c|}{ Immediate skin to skin contact after birth } \\
\hline Yes & - & - & 8 & 20,51 & 12 & 30,77 & 0,4024 \\
\hline
\end{tabular}




\begin{tabular}{|c|c|c|c|c|c|c|c|}
\hline \multirow{3}{*}{ Variables } & \multicolumn{6}{|c|}{ Self-Efficacy in Breastfeeding } & \multirow{3}{*}{ p-valor } \\
\hline & \multicolumn{2}{|c|}{ Low } & \multicolumn{2}{|c|}{ Medium } & \multicolumn{2}{|c|}{ High } & \\
\hline & $\mathbf{n}$ & $\%$ & $\mathbf{n}$ & $\%$ & $\mathbf{n}$ & $\%$ & \\
\hline No & 2 & 5,13 & 8 & 20,51 & 9 & 23,08 & \\
\hline \multicolumn{8}{|c|}{ Complications during hospital stay } \\
\hline Yes & 4 & 8,00 & 4 & 8,00 & 3 & 6,00 & $0,0214^{*}$ \\
\hline No & 2 & 4,00 & 13 & 26,00 & 24 & 48,00 & \\
\hline \multicolumn{8}{|l|}{ Newborn sent to sector } \\
\hline Together with mother & 2 & 4,00 & 14 & 28,00 & 25 & 50,00 & $0,0058^{*}$ \\
\hline UCI & 4 & 8,00 & 3 & 6,00 & 2 & 4,00 & \\
\hline
\end{tabular}

Fisher's Exact Test; *Statistically significant value

\section{DISCUSSION}

The prevalence of intimate partner violence in the current pregnancy in the study population was $17.59 \%$. In a study of women living in 15 municipalities of São Paulo, who had experienced violence in their lifetime, verified predominant ages of 18-49 years. ${ }^{15}$ It was found that the prevalence of the intimate partner violence shown variable is dependent on the methodology used and the place / country where the study was conducted, in addition to cultural, socioeconomic and demographic factors. It is what was verified by authors through integrative review, which examined the prevalence and factors associated with intimate partner violence during the period of gestation, from 45 scientific based productions of general health sciences, during the years 2007 and 2012. Ranges from 3.2\% to 43.1\% were found. ${ }^{16}$

On the characterization of violence, we find that the psychological kind is most often followed by physical and sexual, and this result was also observed in the cited integrative review above, where the highest rates are psychological violence in the current pregnancy, ranging from $16 \%$ to $46.9 \%$, physical violence between $3.6 \%$ and $21 \%$ and sexual forms between $3 \%$ and $9.1 \%{ }^{16}$

Although statistically significant results between type of intimate partner violence during the pregnancy and duration of exclusive breastfeeding at 30 days postpartum were found, many women $(40.43 \%)$ who reported psychological violence and $23.40 \%$ of those who reported physical violence were not practicing exclusive breast feeding. At 70 days postpartum, only $19 \%$ and $8 \%$ of the mentioned women who suffered psychological and physical violence, respectively, continued exclusive breast feeding.
Women in situations of violence can have, postpartum depression, anxiety, harmful lifestyles, such as tobacco and alcohol abuse, eating disorders, risky sexual behavior, sleep disorders, and low self-esteem and self-efficacy. All these factors are related to the occurrence of premature weaning. ${ }^{17}$ In this regard, the study shows that the chances of the present indicative of depressive disorder were approximately four times higher among women in intimate partner violence situations during pregnancy. The same author also demonstrated that women in IPV situations had higher symptom scores of trait anxiety and state anxiety when compared to those who did not suffer violence. ${ }^{18}$ According to other authors, anxiety can cause a negative perception of the nursing mother about their milk production. Also it could cause them to not get involved with breastfeeding, believing that they are not able to develop it successfully. ${ }^{19}$

Most of the women who reported partner violence had high self-efficacy in breastfeeding and statistically significant association between self-efficacy level of breastfeeding and the type of intimate partner violence during pregnancy were not verified in this study. In the literature, we find no studies that analyzed the self-efficacy level in breastfeeding among women in intimate partner violence situations, which allows comparison. However, studies report the result of violence during pregnancy in which women cause important psycho-emotional changes. ${ }^{18}$ In addition, relevant variables that can interfere with the confidence level of women in their ability to breastfeed, includes the support and the partner's incentive for this practice. ${ }^{20}$

Studies evaluating self-efficacy in breastfeeding brought evidence to the fact that women with higher levels of self-efficacy in breastfeeding tend to breastfeed for longer. ${ }^{21,23}$ In this direction, we find 
that the exclusive breastfeeding time was associated with the self-efficacy level in breastfeeding, most women with high self-efficacy (52\%) were breastfeeding 30 days postpartum, and $38.3 \%$ of them practiced exclusive breastfeeding.

The correlation between the factors that can influence the practice of breastfeeding and the level of self-efficacy showed a trend which showed, the earlier prenatal care was started and the greater number consultations attended, the higher self-efficacy levels are in breastfeeding. Some studies indicate that women in situations of violence tend to seek late prenatal care and attend fewer consultations. ${ }^{24} \mathrm{~A}$ pre-experimental study, developed in a public maternity hospital in Fortaleza-CE, with 100 mothers, showed that having received prenatal care was one of the factors that influenced self-efficacy in breastfeeding. ${ }^{25}$ In a randomized clinical trial conducted with 110 primapara women on the effects of a pre-natal breastfeeding workshop, the authors found that $87 \%$ of participants had decided to breastfeed, and among these $78 \%$ had attended pre-natal classes. ${ }^{26}$ In this sense, the orientations given pre-natally may also be a way to improve self-efficacy levels in breastfeeding. ${ }^{27}$

Other factors that the literature presented is a possible effect on breastfeeding related to the characteristics of newborns. In the present study, we identified the association between the Apgar score in the first minute of life and self-efficacy in breastfeeding ( $\mathrm{p}$-value $<0.0001$ ). We found that $50 \%$ of women whose children obtained Apgar 7-10 in the first minute of life, had high self-efficacy in breastfeeding. In another study it was found that the better the vital conditions of newborns, the higher self-efficacy mothers have to breastfeed, because they will feel more secure when dealing with a healthy baby with adequate suckling.

The separation of mother and baby immediately after delivery for infants with complications and residing in the Intermediate Care Unit (ICU), was associated with the level of self-efficacy ( $\mathrm{p}$ value 0.0058 and 0.0214 , respectively). We found that $48 \%$ of women whose children did not have complications during hospitalization and 50\% of those who remained with the mothers during hospitalization, had high self-efficacy in breastfeeding. Some authors found similar results in their study, which showed a relationship between mother and child who remain rooming together with the type of breastfeeding. ${ }^{28}$ The authors believe that separation can reduce maternal confidence in breastfeeding. Anxious mothers find it difficult to understand and interpret their own emotions, decreasing the perception and understanding of the signs shown by the baby. ${ }^{29}$ Moreover, the level of anxiety is a negative factor in self-efficacy in breastfeeding. ${ }^{30}$

Methodological limitations emphasize this research, because it is a cross-sectional study, useful to formulate hypotheses and verify frequency of an outcome, but does not allow inferences about cause and effect, i.e. it is n possible to compare women in intimate partner violence situations or those not in a intimate partner violence situation, in relation to self-efficacy compared to the level and duration of breastfeeding for exclusive breastfeeding.

\section{CONCLUSION}

The results of this study are relevant, as they allow some approaches to factors related to breastfeeding, which can have both positive and negative influences on the initiation and establishment of breastfeeding as well as for early weaning.

The intimate partner violence situations put women in unfavorable conditions for breastfeeding. In this sense, as implications for clinical practice and research, it reinforces the need for the training of health professionals and studies analyzing the impact of intimate partner violence in breastfeeding. Health professionals need to be prepared to not only identify the cases, but also act appropriately in order to minimize possible damage. Future investigations should be carried out by means of longitudinal studies to examine the maintenance of breastfeeding and the influence of self-efficacy with women in situations of violence, and the identification of recurrence of intimate partner violence during breastfeeding, which would allow deepening of the complexity that involves these two experiences, experienced simultaneously by women.

It is worth considering that this study is the first to examine such an issue and, also as an indicator of self-efficacy in breastfeeding and the use of BSES is revealed as a tool that can be used both in research and in service, allowing the health professional to plan care more effectively.

\section{REFERÊNCIAS}

1. Silva WF, Guedes ZCF. Tempo de aleitamento materno exclusivo em recém-nascidos prematuros e a termo. Rev CEFAC [Internet]. 2013 [cited 2016 Apr 16]; 15(1):160-71. Available from: http://www. scielo.br $/$ scielo.php?script=sci_arttext\&pid $=$ S151618462013000100019\&lng=en\&nrm=iso 
2. Lourenço MA, Deslandes SF. Experiência do cuidado materno e amamentação sob a ótica de mulheres vítimas de violência conjugal. Rev Saúde Pública. 2008; 42(4):615-21.

3. Oliveira ASD. Violência entre parceiros íntimos durante a gestação: um fator de risco para o desmame precoce? [tese]. Rio de Janeiro: Universidade do Estado do Rio de Janeiro; 2008.

4. Brasil. Secretaria Nacional de Enfrentamento à Violência contra as Mulheres. Secretaria de Políticas para as Mulheres. Política Nacional de Enfrentamento à Violência contra as Mulheres. Brasília (DF): Presidência da República; 2011.

5. FrankS, Coelho EBS, Boing AF. Perfil dos estudos sobre violência contra a mulher por parceiro íntimo: 2003 a 2007. Rev Panam Salud Publica. 2010; 27(5):376-81.

6. Rodrigues AP, Padoin SMM, Paula CC. Laura AG. Fatores que interferem na autoeficácia da amamentação: revisão integrativa. Rev Enferm UFPE on line [Internet]. 2013 [cited 2016 Apr 16]; 7(Esp):4144-52. Available from: http:/ / www.revista. ufpe.br/revistaenfermagem/index.php/revista/ article/download/4031/6315.

7. Bandura A. Self-efficacy: toward a unifying theory of behavioral change. Psychological Review. 1977; 84(2):191-215.

8. Dennis CL, Faux, S. Development and psychometric testing of the Breastfeeding Self-Efficacy Scale. Res Nurs Health. 1999 Oct; 22(5):399-409.

9. World Health Organization. Multi-coutry study on women's health and domestic violence against women: summary report of initial results on prevalence, health outcomes and women's responses. Geneva (CH): WHO; 2005.

10. Schraiber LB, Latorre MRDO, França Júnior I, Segri NJ, D'Oliviera AFPL. Validade do instrumento WHO VAW STUDY para estimar violência de gênero contra a mulher. Rev Saúde Pública. 2010; 44(4):658-66.

11. Oriá MOB, Ximenes LB. Tradução e adaptação cultural da Breastfeeding Self-efficacy Scale para o português. Acta Paul Enferm. 2010; 23(2):230-8.

12. Oriá MOB, Ximenes LB, Almeida PC, Glick DF, Dennis CL. Psychometric assessment of the Brazilian version of the Breastfeeding Self-Efficacy Scale. Public Health Nurs. 2009; 26(6):574-83.

13. World Health Organization. Indicators for assessing infant and young child feeding practices. Conclusions of a consensus meeting held 6-8 Nov 2007. Geneva (CH): WHO; 2008.

14. Ministério da Saúde (BR). Resolução no 466, de 12 de dezembro de 2012: dispõe sobre pesquisa envolvendo seres humanos. Brasília (DF): Ministério da Saúde; 2012.

15. Osis MJD, Duarte GA, Faundes A. Violência entre usuárias de unidades de saúde: prevalência, perspectiva e conduta de gestores e profissionais.
Rev Saúde Pública. [Internet] 2012 [cited 2013 Feb 4]; 46(2). Available from: http://www.scielosp. org / scielo.php?script=sci_arttext\&pid=S0034$89102012000200018 \& \operatorname{lng}=\mathrm{en \& n}$ rm=iso

16. Puccia MIR, Mamede MV. Revisão integrativa sobre a violência por parceiro íntimo na gestação. Rev Eletr Enferm [Internet]. 2012 [cited 2016 Apr 16]; 14(4):94456. Available from: https://www.fen.ufg.br/revista/ v14/n4/pdf/v14n4a24.pdf

17. Kendall-Tackett K A. Violence against women in the perinatal period: the influence of lifetime violence and abuse on pregnancy and postpartum. Trauma Psychol News. 2008; 3(1):8-11.

18. Fonseca-Machado MO. Violência na gestação e saúde mental de mulheres que são vítimas de seus parceiros [tese]. Ribeirão Preto (SP): Universidade de São Paulo, Escola de Enfermagem de Ribeirão Preto; 2014.

19. Boucher CA, Brazal PM, Graham-Certosini C, Carnaghan-Sherrard K, Feeley N. Mothers' breastfeeding experiences in the NICU. Neonatal Netw. 2011 Jan-Feb 1;30(1):21-8.

20. Mannion CA, Hobbs AJ, McDonald SW, Tough SC. Maternal perceptions of partner support during breastfeeding. Int Breastfeed J [Internet]. 2013 May 8 [cited 2016 Apr 10];8(1):4. Available from: http:// www.internationalbreastfeedingjournal.com/ content $/ 8 / 1 / 4$

21. Mcqueen KA, McQueen KA, Dennis CL, Stremler $\mathrm{R}$, Norman CD. A pilot randomized controlled trial of breastfeeding self-efficacy intervention with primiparous mothers. J Obstet Gynecol Neonatal Nurs. 2011 Jan-Feb; 40(1):35-46.

22. Uchoa JL. Autoeficácia das mulheres no ciclo gravídico-puerperal em amamentar [dissertação]. Fortaleza (CE): Universidade Federal do Ceará; 2012.

23. Dennis CL, Heaman M, Mossman M. Psychometric testing of the Breastfeeding Self-Efficacy Scale-Short form among adolescents. J Adolesc Health. 2011; 49(3):265-71.

24. Quelopana AM, Champion JD, Salazar BC. Health behavior in Mexican pregnant women with a history of violence. West J Nurs Res. 2008; 30(8):1005-18.

25. Dodt RCM, Ferreira AMV, Nascimento LA, Macêdo AC, Joventino ES, Ximenes LB. Influência de estratégia de educação em saúde mediada por álbum seriado sobre a autoeficácia materna para amamentar. Texto Contexto Enferm [Internet]. 2013 [cited 2016 Apr 16]; 22(3):610-8. Available from: http:// www.scielo.br/scielo.php?script=sci arttext\&pid=S0104-07072013000300006

26. Noel-Weiss J, Rupp A, Cragg B, Bassett V, Woodend AK. Randomized controlled trial to determine effects of prenatal breastfeeding workshop on maternal breasteeding self-efficacy and breastfeeding duration. J Obstet Gynecol Neonatal Nurs. 2006 Sep-Oct; 35(5):616-24. 
27. Dodt RCM. Elaboração e validação de tecnologia educativa para autoeficácia da amamentação [tese]. Fortaleza (CE): Universidade Federal do Ceará; 2011.

28. Narchi NZ, Fernandes RAQ, Dias DHN. Variáveis que influenciam a manutenção do aleitamento materno exclusivo. Rev Esc Enferm USP. 2009; 43(2):87-94.

29. Feeley N, Zelkowitz P, Westreich R, Dunkley, D. The evidence base for the cues program for mothers of very low birth weight infants: an innovative approach to reduce anxiety and support sensitive interaction. J Perinat Educ. 2011; 20(3):142-53.

30. Wilhelm SL, Rodehorst TK, Stepans MBF, Hertzog $\mathrm{M}$, Berens $\mathrm{C}$. Influence of intention and selfefficacy levels on duration of breastfeeding for midwest rural mothers. Applied Nurs Res. [Internet] 2008; 21(3). [cited 2014 May 7]. Available from: http:/ / www.sciencedirect.com/science/article/pii/ S0897189706001364 